\title{
Koronarsykdom hos kvinner og menn: Fellestrekk og ulikheter i forekomst, risikofaktorer og behandling
}

\author{
Inger Njølstad og Maja-Lisa Løchen \\ Institutt for samfunnsmedisin, Universitetet i Tromsø, 9037 Tromsø \\ Korrespondanse: Inger Njølstad, telefon: 77644816 telefax: 77644831 E-post: inger.njolstad@ism.uit.no
}

\begin{abstract}
SAMMENDRAG
Kardiovaskulær sykdom er viktigste dødsårsak for både kvinner og menn. Koronarsykdom forekommer omtrent like hyppig i de to kjønn, men kvinner er gjennomsnittlig 10 år eldre enn menn ved sykdomsdebut. Sett under ett har kvinner høyere komplikasjonsrate ved infarkt og høyere infarktletalitet under sykehusopphold enn menn, men mye av kjønnsulikhetene som er rapportert, skyldes ulik alderssammensetning og komorbiditet i pasientpopulasjonen. Betydningen av enkelte koronare risikofaktorer, som røyking og triglyserider, synes å være forskjellig for kvinner og menn, mens andre risikofaktorerer er like viktige i de to kjønn. Det er viktig å foreta kjønnsspesifikke analyser med aldersspesifikke sammenligninger eller adekvate multivariate justeringer for å få belyst om observerte kjønnsulikheter i koronarsykdom har et reelt biologisk eller sosialt grunnlag, eller skyldes ufullstendig justering for konfunderende faktorer.
\end{abstract}

\section{KARDIOVASKULAR DØDELIGHET OG UT- VIKLING AV KORONARDØDELIGHET}

Kardiovaskulær sykdom er den hyppigste dødsårsak for kvinner og menn i Norge. I 1995 døde 4409 kvinner og 6053 menn av ischemisk hjertesykdom og plutselig død (ICD-9 410-414, 798.1). Det utgjorde henholdsvis $19,9 \%$ og $26,3 \%$ av alle dødsfall. Akutt hjerteinfarkt er den viktigste diagnosen i denne sykdomsgruppen. Cerebrovaskulær sykdom (ICD-9 430438) var årsak til død hos $2917(13,2 \%)$ kvinner og $2070(9,0 \%)$ menn. Til sammenligning døde 4952 kvinner $(22,3 \%)$ og 5700 menn $(24,8 \%)$ av svulster. Blant kvinner er mortaliteten av ischemisk hjertesykdom høyere enn mortaliteten av brystkreft (1).

Forekomsten av ischemisk hjertesykdom økte kraftig etter den annen verdenskrig og kulminerte i Norge omkring 1970. Fra midt på 1970-tallet har det vært en klar nedgang i koronardødeligheten, som nå er lavere enn i 1950-årene både blant kvinner og menn (1). I Norge som i de fleste vest-europeiske land har koronardødeligheten for begge kjønn i aldersgruppen 45-74 år sunket med gjennomsnittlig 1-2\% per år fra 1970 til 1992 (2).

\section{KJØNNSFORSKJELLER I FOREKOMST AV KORONARSYKDOM}

Økningen i koronarsykdom etter krigen var kraftigst blant menn, og i alle aldersgrupper har menn høyere koronardødelighet enn kvinner (1). I Finnmarksundersøkelsen var insidensen av hjerteinfarkt 4,6 ganger høyere blant menn enn kvinner i en 12-års oppfølging av aldersgruppen 35-52 år (3). Likevel er det en myte at hjerteinfarkt er en mannssykdom. Kvinner er i gjennomsnitt ti år eldre enn menn ved førstegangs hjerteinfarkt, og de aldersspesifikke dødsrater for kvinner er omlag de samme som for ti år yngre menn (Tabell 1). Den aldersrelaterte økningen i koronarsykdom skjer jevnt (4), uten noen "knekk i kurven" ved vanlig menopausealder for kvinner. Økningen er derimot litt lavere for menn i høyere aldersgrupper. Det fører til at ratene for menn og kvinner nærmer seg hverandre med alderen (4).

Tabell 1. Aldersspesifikk dødelighet av ischemisk hjertesykdom (ICD-9 410-414) blant menn og kvinner. Rater per 100 000. Norge 1995.

\begin{tabular}{lrr}
\hline Alder (år) & Menn & Kvinner \\
\hline $15-24$ & 0,3 & - \\
$25-34$ & 2,3 & 0,3 \\
$35-44$ & 20,0 & 3,6 \\
$45-54$ & 92,5 & 14,3 \\
$55-64$ & 333,2 & 82,8 \\
$65-74$ & 951,9 & 340,4 \\
$75+$ & 2546,1 & 1545,1 \\
\hline
\end{tabular}

Kilde: Statistisk sentralbyrå (1).

Koronarsykdom kan ytre seg klinisk i andre former enn som akutt hjerteinfarkt. I følge Framinghamundersøkelsen gjennomgår kvinner oftere stumt infarkt og har oftere angina pectoris som debut-manifestasjon (5). Imidlertid fant Coronary Artery Surgery Study 
(CASS) lavere andel av verifisert koronarsykdom blant kvinner enn menn med "typisk" angina (henholdsvis $72 \%$ og 93\%) (6). Blant pasienter henvist til koronar bypassutredning i CASS-studien hadde 50\% av kvinnene og $17 \%$ av mennene ingen eller ubetydelig aterosklerotisk innsnevring i koronarkarene (7). Det kan muligens være forklaringen på at klinisk angina pectoris synes å ha en gunstigere prognose blant kvinner enn menn $(5,8)$.

Kvinner er gjennomsnittlig eldre og har høyere forekomst av aldersrelatert komorbiditet enn menn, blant annet diabetes, hypertensjon og hjertesvikt, når de rammes av infarkt (9-11). Brystsmerter hos kvinner oppfattes ikke alltid som tegn på infarkt, og bidrar til forsinket sykehusinnleggelse for kvinner med hjerteinfarkt i forhold til menn $(11,12)$. Det er usikkert om kvinner har hyppigere forekomst av non-Q-infarkt (13). Derimot får kvinner oftere komplikasjoner ved akutt hjerteinfarkt, blant annet i form av hjertesvikt og lungeødem $(9,13)$. Om dette skyldes høyere alder og komorbiditet eller mindre kollateral-utvikling i hjertemuskulaturen, er usikkert (13).

\section{OVERLEVELSE ETTER HJERTEINFARKT}

Mange studier har rapportert om høyere letalitet hos kvinner ved akutt hjerteinfarkt, men metodologiske forhold kan forklare mye av den tilsynelatende kjønnsulikheten i infarktletalitet (9). Høy alder $(14,15)$, diabetes, hypertensjon og hjertesvikt $(9,15)$ er viktige risikofaktorer for dødelig utgang ved akutt infarkt, som alle går i kvinners disfavør. En oversikt over 27 studier (9) viste at ujusterte dødelighetsrater som regel var høyere for kvinner de første ukene etter infarktet, men justering for alder og eventuelt andre risikofaktorer reduserte overdødeligheten til $<20 \%$ i nesten alle studiene. Blant 9600 kvinner og 26500 menn med infarkt i ISIS-3 studien (12), var ujustert odds ratio for død innen 35 dager 1,73 (95\% konfidensintervall (KI) $1,61-1,86)$ for kvinner i forhold til menn. Etter multivariat justering var odds ratio (OR) 1,14 (95\% KI 1,05-1,23). I en undersøkelse fra Seattle 1988-1994 (16) var aldersjustert dødelighet under sykehusopphold $20 \%$ høyere blant kvinner (OR 1,22; 95\% KI $1,06-1,39)$. En stor amerikansk infarktundersøkelse i perioden 1994-1998 viser at yngre, men ikke eldre kvinner, har høyere risiko enn menn på samme alder for å dø under sykehusoppholdet (11). I de fleste (9, 16), men ikke alle (10) studier er derimot langtidsoverlevelsen like god eller bedre blant kvinner. Hvorfor kvinner med hjerteinfarkt har lenger tid mellom symptompresentasjon og innleggelse, høyere prevalens av ustabil angina tross mindre utbredte angiografiske forandringer i koronarkar, og høyere komorbiditet enn menn på samme alder med infarkt, er ukjent og fordrer videre forskning (17).

Sett under ett synes kvinner å ha en litt høyere infarktletalitet enn menn på tilsvarende alder, vel å merke i sykehusbaserte studier og i de første ukene etter infarktet. Siden $2 / 3$ av infarktdødsfallene skjer utenfor sykehus (18), vil slike undersøkelser ikke fange opp eventuelle kjønnsulikheter i den aller første fasen. I en studie fra New Zealand var infarktletaliten før hospitalisering høyere blant menn, men etter innleggelse høyere blant kvinner, og 28-dagers infarktletalitet var lik i de to kjønn (19). Den internasjonale populasjonsbaserte MONICA-studien inkluderer hjerteinfarkt i og utenfor sykehus. En analyse av 80.000 førstegangs infarkttilfeller blant 5,7 millioner kvinner og menn i alderen 35-64 år (18), viste at median 28dagers letalitet var $49 \%$ (variasjonsbredde $35-60 \%$ ) blant menn og 51\% (34-70\%) blant kvinner. Letaliteten var høyere blant kvinner særlig i land med lav forekomst av koronarsykdom. Blant de sykehusinnlagte var median 28 -dagers letalitet $22 \%$ (15-36\%) for menn og 27\% (19-46\%) for kvinner. I Finnmarksundersøkelsen var det ingen kjønnsforskjell i infarktoverlevelse etter 4 uker, og heller ikke etter ett år (15). Studien inkluderte førstegangs infarkttilfeller i og utenfor sykehus i tiden 1974 til 1989, og det er ikke kjent hvordan overlevelsen etter hjerteinfarkt har vært i Norge på 1990-tallet.

\section{BETYR RISIKOFAKTORENE DET SAMME FOR KVINNER OG MENN?}

\section{Royking}

Tobakksrøyking er den ledende risikofaktor for død som kan forebygges. For middelaldrende kvinner er røyking den viktigste risikofaktoren for hjerteinfarkt, fulgt av høyt serumkolesterol og hypertensjon (3). Flere studier viser at røyking er en mer ugunstig risikofaktor for hjerteinfarkt for kvinner enn for menn $(3,20,21)$. I Finnmarksundersøkelsen var kvinners insidensrate for hjerteinfarkt seks ganger høyere dersom de røykte mer enn 20 sigaretter daglig sammenlignet med aldri-røykende kvinner, mens tilsvarende risiko$ø$ kning for menn var tre (3). Stor-røykende kvinner hadde like høy risiko for hjerteinfarkt som ikkerøykende menn. Daglig røyking var en sterkere risikofaktor for hjerteinfarkt for kvinner (relativ risiko (RR) 3,3; 95\% KI 2,1-5,1) enn for menn (RR 1,9; 95\% KI $1,6-2,3)$. Blant de yngste kvinnene medførte røyking en relativ risiko på $7,1(95 \%$ KI 2,6-19,1). De norske resultatene støttes av en stor dansk undersøkelse der man fant en relativ risiko på $2,2(95 \% \mathrm{KI} 1,9-2,7)$ for kvinner og 1,4 (95\% KI 1,3-1,6) for menn, som gir en kjønnsforskjell i relativ risiko på 50\% (21). Den økte risikoen hos yngre kvinner ble ikke bekreftet i denne studien. Årsaken til kvinners relative sensitivitet for tobakk er ikke kjent, men tobakkens antiøstrogene effekt har vært foreslått som mediator (22). Kvinnelige røykere har dessuten en større reduksjon i HDLkolesterol sammenlignet med mannlige røykere (3). 
Etter røykeslutt vil risikoen for hjerteinfarkt for begge kjønn reduseres med 50\% i løpet av ett år (23) og nå risikonivået til ikke-røykere innen tre-fem år, uavhengig av den totale dose som er blitt røykt (24). Dette kan tyde på at korttidseffekten av røyking, sannsynligvis på det hemodynamiske systemet, er viktigere enn den totale eksposisjonens effekt på ateroskleroseutviklingen.

Norske kvinner røyker mer enn tidligere, mens menn røyker mindre (25). I aldersgruppen 16-74 år røyker gjennomsnittlig $34 \%$ av befolkningen daglig. Dersom ikke røyking blant kvinner avtar, vil det kunne påvirke den ellers ventede reduksjonen av insidensen av hjerteinfarkt hos kvinner i ugunstig retning. Mange kvinner røyker såkalte lett-sigaretter, men slike produkter synes å gi like høy risiko som vanlige sigaretter (26).

\section{Lipider}

Høyt totalkolesterol i serum er en viktig risikofaktor for hjerteinfarkt hos begge kjønn $(3,27)$. I enkelte observasjonsstudier ser det ut til at risikoøkningen starter ved høyere kolesterolverdier for kvinner enn for menn $(3,27)$. Premenopausale kvinner har høyere serumkonsentrasjoner av HDL-kolesterol enn menn, og HDL-kolesterol er en like sterk risikofaktor for infarkt i begge kjønn (3).

Triglyserider framstår som en koronar risikofaktor i univariate analyser (3) og er en sterkere risikofaktor for kvinner $(28,29)$, men mister som regel sin prediktive verdi hvis HDL-kolesterol inkluderes i samme regresjonsmodell (3).

Kvinner med diabetes har 3-7 ganger høyere risiko for hjerteinfarkt sammenlignet med andre kvinner, mens tilsvarende risikoøkning for menn er 2-3 (30). Diabetes opphever dermed kjønnsforskjellen i hjerteinfarkt blant yngre og middelaldrende personer. Det hevdes ofte at diabetes har en mer aterogen virkning hos kvinner (30). Imidlertid har både diabetiske og pre-diabetiske kvinner lipidkonsentrasjoner på samme nivå som menn, i motsetning til den ikke-diabetiske befolkning der premenopausale kvinner har en gunstigere lipidprofil (31). I Finnmarks-undersøkelsen var HDL-kolesterol en sterk risikofaktor for diabetes hos kvinner, men ikke hos menn (31). Kjønnsforskjellen i forholdet mellom diabetes og koronarsykdom er langt fra kartlagt, og utgjør et interessant forskningsfelt.

\section{Blodtrykk}

Assosiasjonen mellom blodtrykk og koronardødelighet finnes hos begge kjønn, men risikoøkningen forbundet med $15 \mathrm{mmHg}$ blodtrykksøkning er noe høyere for kvinner i alle aldersgrupper opp til 70 år (32). Likevel er mortaliteten høyere blant menn i alle blodtrykkskategorier og aldersgrupper. Absolutt risiko for hjerneslag er også høyere for menn i nesten alle kategorier
(32). Tross dette står flere kvinner enn menn på hypertensjonsbehandling i Norge $(3,32,33)$.

\section{Fysisk aktivitet}

Det er generelt akseptert at fysisk aktivitet er assosiert med redusert infarktrisiko hos menn (34). Studier blant kvinner har vist varierende resultater. Enkelte mindre studier fant $60-75 \%$ lavere risiko for hjerteinfarkt hos fysisk aktive $\mathrm{i}$ forhold til inaktive kvinner $(35,36)$, mens en stor prospektiv amerikansk studie fant ingen riskoreduksjon blant fysisk aktive kvinner, men derimot blant menn (37). En mulig forklaring på den observerte kjønnsforskjellen kan være at utformingen av spørreskjema ofte gir større tendens til misklassifisering av kvinners aktivitetsnivå, for eksempel fordi hardt husarbeid ikke passer inn i en høy aktivitetskategori $(38,39)$. En studie blant mer enn 3000 kvinner fulgt $\mathrm{i}$ åtte år fant at risikoen for død (hovedsakelig kardiovaskulær død) økte kraftig ved lavere fysisk kapasitet (40). Kvinner i laveste kvintil hadde en relativ risiko for død på $1,9(95 \% \mathrm{KI} 1,3-2,9)$ sammenlignet med alle andre kategorier av fysisk kapasitet. Fordi fysisk aktivitet er positivt assosiert med fysisk kapasitet (41), støtter denne studien påstanden om at studier om kvinner, fysisk aktivitet og hjerteinfarkt kan ha misklassifisert kvinner som inaktive mens de egentlig tilhørte en mer aktiv kategori.

Fysisk aktivitet påvirker i gunstig retning blodtrykk (42), LDL-kolesterol, HDL-kolesterol (43) og insulinog sukkeromsetningen (44), både direkte og indirekte gjennom vektnedgang (45). Det har vært hevdet at kvinner har en annen fysiologisk respons på fysisk aktivitet enn menn når det gjelder BMI (46) og lipidnivåer (47). En norsk studie tyder imidlertid på at kvinner har samme effekt av fysisk aktivitet som menn (43). Selv om det hittil er få studier som viser en positiv effekt $\mathrm{i}$ forhold til hjerteinfarkt hos fysisk aktive kvinner, gir assosiasjonen mellom fysisk aktivitet og risikofaktorer grunn til å forvente at en slik effekt er til stede.

\section{HVORFOR HAR KVINNER OG MENN ULIK RISIKO FOR HJERTEINFARKT?}

Årsaken til at kvinner har lavere absolutt risiko for hjerteinfarkt er ikke kjent. Noe kan nok skyldes kjønnsulikheter i røykevaner og kosthold, som igjen kan påvirke lipidnivå og blodtrykk, men det gjenstår en forskjell som ikke forklares av de klassiske risikofaktorene. Mange har ment at kjønnsforskjellen i insidens av hjerteinfarkt skyldes en gunstig effekt av kvinnelige kjønnshormoner, spesielt østrogen. Imidlertid stiger kvinners insidens av hjerteinfarkt jevnt i årene omkring menopausen da østrogen reduseres kraftig (4). Det kan tyde på at østrogen ikke er hovedforklaringen på kvinners relative beskyttelse i forhold til like gamle menn. Heller ikke testosteron sin rolle i forhold til koronarsykdom er avklart. Noen studier antyder at 
nøkkelen til kjønnsforskjellen i hjerteinfarkt ligger i metabolske og hormonelle kjønnsforskjeller som er assosiert med den ulike fettfordelingen hos kvinner og menn. Kvinner med mannlig fettfordeling er mer utsatt enn andre kvinner for å få metabolsk syndrom med lavt HDL-kolesterol, høyt triglyseridnivå, hypertensjon og forstyrrelser i glukosemetabolismen, som igjen øker risikoen for diabetes (48). Maskulin fettfordeling har vist seg å øke risikoen for hjerteinfarkt både blant kvinner og menn (49). Dersom vi visste hvorfor noen kvinner får en "mannlig" risikoprofil, ville vi trolig være kommet et langt skritt videre i å forstå kjønnsforskjellene i forekomsten av koronarsykdom.

\section{ER RESULTATENE AV FOREBYGGING OG BEHANDLING VED KORONARSYKDOM LIKE BRA FOR KVINNER OG MENN?}

\section{Blodtrykksbehandling}

Mer enn halvparten av deltakerne i de randomiserte, placebo-kontrollerte blodtrykksforsøkene er kvinner, men ikke alle studiene har inkludert kvinner eller publisert kjønnsspesifikke resultater. I en metaanalyse (50) som omfattet sju av 15 slike studier var det blant kvinner signifikant behandlingseffekt på hjerneslag og alvorlige kardiovaskulære hendelser, men ikke på total mortalitet og koronare hendelser. Blant menn var det signifikant behandlingseffekt for alle typer endepunkter. Det var ingen interaksjon mellom kjønn og behandlingseffekt, og kjønnsforskjellen mht. signifikans for noen endepunkter kan skyldes lavere morbiditetsog mortalitetsrater blant kvinner i de undersøkte aldersgrupper. Den absolutte effekten av blodtrykksbehandling blir dermed også mindre blant kvinner enn blant menn.

\section{Kolesterol-senkende behandling}

Man anbefaler nå at kolesterolnivået i serum bør være lavere enn $5,0 \mathrm{mmol} / \mathrm{l}$. I Norge er gjennomsnittlig kolesterolverdi for 40-42 åringer 5,4 mmol/l blant kvinner og 5,8 mmol/l blant menn (51). Data for menn i prospektive observasjonsstudier og i kliniske randomiserte forsøk tyder på at $0,6 \mathrm{mmol} / 1$ (ca. $10 \%$ ) reduksjon i totalkolesterol medfører 50\% reduksjon i risiko for infarkt ved 40 års alder, $40 \%$ ved 50 år, 30\% ved 60 år og 20\% ved 70 år og eldre (52). Færre data er publisert for kvinner, men kolesterolreduksjon synes å gi tilsvarende resultater (52). I et placebokontrollert forsøk med statiner ved asymptomatisk karotisaterosklerose (53), ble det påvist nedgang i IMT (intima media tykkelse) i samme grad blant kvinner og menn. I den sekundærpreventive 4S studien med statinbehandling ved moderat forhøyet totalkolesterol hadde $69 \%$ av kvinnene og $73 \%$ av mennene oppnådd serum totalkolesterol $<5,2 \mathrm{mmol} / \mathrm{l}$ etter ett år. Kvinner og menn hadde like stor reduksjon i relativ risiko for alvorlige koronare hendelser (54). Blant de 827 kvin- nene i 4S var det kun 28 dødsfall i simvastatingruppen og 25 dødsfall i placebogruppen (RR 1,16; 95\% KI $0,68-1,99)$, mens det blant menn var $35 \%$ reduksjon $\mathrm{i}$ total dødelighet (RR 0,$65 ; 95 \%$ KI $0,53-0,80)$. I et sekundærpreventivt forsøk med statinbehandling ved gjennomsnittlig kolesterolnivå $(5,4 \mathrm{mmol} / \mathrm{l})(55)$, medførte behandling større nedgang i alvorlige koronare hendelser for kvinner (46\% reduksjon, $\mathrm{p}=0,001)$ enn menn $(20 \%$ reduksjon, $p=0.001)(p=0.05$ for interaksjon mellom kjønn og behandlingseffekt). Imidlertid var det ingen signifikant nedgang $i$ total mortalitet $i$ behandlingsgruppen.

\section{Acetylsalisylsyrebehandling}

Kvinner ble ikke inkludert $\mathrm{i}$ de to store primærprofylaktiske forsøk med acetylsalisylsyrebehandling (aspirin) blant engelske (56) og amerikanske (57) leger på slutten av 1980-tallet. Relativt høye doser ble benyttet i studiene blant menn, og ingen nettogevinst på total dødelighet ble påvist, selv om den amerikanske studien fant $44 \%$ reduksjon i hjerteinfarktinsidens blant menn over 50 år (57). En observasjonsstudie fra Nurses' Health Study tyder på at aspirinbruk er assosiert med lavere infarktrisiko også blant kvinner (58), men konklusjoner kan ikke trekkes før resultatene fra det pågående primærprofylaktiske forsøket Women's Health Study (59) foreligger.

\section{Behandling ved akutt hjerteinfarkt}

Verdien av trombolytisk behandling er blitt godt dokumentert på 1990-tallet. Kvinner som får trombolysebehandling synes å ha høyere dødelighet enn menn $(60,61)$, men dette kan reflektere kjønnsforskjellen i infarktletalitet som er påvist i sykehusbaserte studier. Både menn og kvinner hadde nytte av trombolytisk behandling og platehemmere i ISIS-2-studien, men den relative reduksjonen i mortalitet var noe høyere for menn for streptokinase $(27 \%$ vs. $15 \%)$, aspirin (23\% vs. $17 \%$ ) og begge medikamenter (44\% vs. $30 \%$ ) (61). Angiografiske data fra randomiserte fors $ø$ k viser at effekten på koronar reperfusjon og påfølgende reokklusjon er lik for menn og kvinner (60), mens kvinner muligens har noe høyere forekomst av blødningskomplikasjoner (13).

Beta-blokkerbehandling ved akutt infarkt er vel etablert, og effekten synes å være like god for kvinner som for menn (62). Heller ikke for acetylsalisylsyre ved ustabil angina og akutt hjerteinfarkt synes det å være noen kjønnsforskjell i behandlingseffekt (63).

\section{Koronar bypass-operasjoner og PTCA}

Mange tidlige studier rapporterte om høyere mortalitet og flere alvorlige komplikasjoner blant kvinner enn blant menn etter koronar bypass-operasjoner og PTCA. CASS-studien (64) inkluderte 6258 menn og 1153 kvinner i perioden 1975-1980. Operasjonsmortaliteten var høyere blant kvinner (4,5\%) enn blant menn 
(1,9\%) i aldersgruppen 40-59 år. Kvinner har trangere koronarkar enn menn $(64,65)$, og mindre kroppsstørrelse og trangere koronarkar forklarte kjønnsforskjellen i operasjonsmortalitet i CASS. I undersøkelser fra Rikshospitalet i Oslo (66) og fra Stockholm (67) på 1980-tallet var det ingen kjønnsforskjell etter bypassoperasjon i total mortalitet eller hjerteinfarkt etter justering for alder og eventuelt kroppsstørrelse. I en multisenter undersøkelse i USA og Canada (65) ble omkring 1800 pasienter randomisert til enten PTCA eller koronar bypass-operasjon i perioden 1988-1991. Kvinner var eldre og sykere enn menn preoperativt, men sykehusletaliteten var like lav blant kvinner som menn etter bypass-operasjon og PTCA. I begge grupper hadde kvinner høyere forekomst av hjertesvikt og lungeødem etter inngrepet. Kumulativ letalitet etter fem år var henholdsvis $12,8 \%$ og $12,0 \%$ blant kvinner og menn, og det var ingen kjønnsforskjell i forekomst av anginasymptomer og infarkt. Justert for alder og komorbiditet ble langtidsoverlevelsen faktisk bedre for kvinner enn for menn. Også kliniske observasjonsstudier av operative inngrep på 1980-tallet viser at korttids- og langtidsoverlevelsen er lik i de to kjønn etter justering for alder og andre pasientfaktorer som påvirker overlevelsen (68).

\section{FÅR KVINNER OG MENN SAMME BEHAND- LINGSTILBUD VED KORONARSYKDOM?}

En rekke, men ikke alle $(69,70)$ kliniske observasjonsstudier i Europa og USA har dokumentert at kvinner ikke får samme utredning og behandling som menn ved mulig koronarsykdom (71-74) og påvist infarkt $(75,76)$. I en engelsk studie (75) ble $56 \%$ av menn og $41 \%$ av kvinner med antatt hjerteinfarkt innlagt på intensivavdeling. Blant yngre pasienter var det ingen kjønnsforskjell, men eldre kvinner hadde $15 \%$ mindre sjanse enn eldre menn til å bli innlagt. Fordi trombolytisk behandling den gang var forbeholdt intensivavdelingene, hadde kvinner mindre sjanse til å få slik behandling. Vel inne på intensivavdelingene var det ingen kjønnsforskjell i behandlingstilbudet. Steingart og medarbeidere (72) viste $\mathrm{i}$ en studie fra USA og Canada at flere menn enn kvinner fikk utført hjertekateterisering, til tross for at kvinner oppga å være mer hemmet av sin koronarsykdom. Derimot ble koronar bypassoperasjon utført like hyppig i de to kjønn når hjertekateterisering først var utført.

Flere grunner til kjønnsforskjellene i behandling kan tenkes, som at angina betraktes som mindre alvorlig hos kvinner, at stress-testing er mindre konklusivt for kvinner, at kvinner er eldre og har flere kontraindikasjoner mot ulike behandlingstilbud, eller psykologiske faktorer blant leger. Et amerikansk eksperiment med hypotetiske pasienter viste at leger sjeldnere ville henvise kvinner og negre til hjertekateterisering, uavhengig av pretest-sannsynlighet for koronarsykdom
(77). På den annen side viste en gjennomgang av nærmere 6000 tilfeller av dokumentert koronarsykdom (69) at kvinner med alvorlig sykdom ble henvist for koronarutredning i samme grad som menn, mens flere menn ble henvist i lav-risikogruppen, der koronar bypassoperasjon gir liten eller ingen nytte i forhold til medikamentell behandling. Man kan derfor spørre om ikke kjønnsforskjellen i frekvens av bypassoperasjoner like gjerne kan representere et overforbruk blant menn som underforbruk blant kvinner $(69,71,73)$.

\section{ØSTROGEN, MENOPAUSE OG KORONAR- SYKDOM HOS KVINNER}

Menopausens innvirkning på koronare risikofaktorer er ikke helt avklart (78). Man antar at østrogen kan beskytte mot koronarsykdom dels via en gunstig effekt på LDL- og HDL-kolesterolnivået og dels via en direkte effekt på blodårer, koagulasjonssystemet og det fibrinolytiske system (79). Derimot øker triglyseridnivået i serum med 15-40\% ved P-pillebruk og med 5$10 \%$ ved peroral østrogenbehandling (29). Om dette har noen klinisk betydning er usikkert. Transdermal hormonbehandling synes ikke å påvirke triglyseridnivået (29).

Flere observasjonsstudier har vist en mulig sammenheng mellom tidlig menopause og koronarsykdom, deriblant en studie blant adventister, som sterkt fraråder røyking av religiøse grunner (80). Blant 35.000 kvinner i Nurses' Health Study som ikke brukte østrogensubstitusjon og som ble fulgt i 18 år, ble imidlertid økt risiko observert blant røykere, men ikke blant aldri-røykere (81). Forfatterne postulerer at den tilsynelatende økte risikoen ved tidlig naturlig menopause kan reflektere residualkonfundering av røyking.

\section{OSTROGENBEHANDLING SOM PRIMAR- OG SEKUNDARPROFYLAKSE FOR HJERTEINFARKT}

Det diskuteres om østrogenbruk forebygger hjerteinfarkt $(82,83)$. Noen observasjonsstudier (84) finner at postmenopausal østrogenbruk er assosiert med lavere risiko for hjerteinfarkt, mens andre finner ingen slik effekt (85). I Nurses' Health Study var østrogenbruk assosiert med opptil $60 \%$ reduksjon i risiko for hjerteinfarkt $(86,87)$, og en metaanalyse av 25 studier fant en relativ risiko på 0,7 for koronarsykdom blant østrogenbrukere (84). Imidlertid foreligger det ennå ingen resultater fra primærprofylaktiske randomiserte kliniske forsøk med østrogensubstitusjonsbehandling mot hjerteinfarkt. Det første sekundærprofylaktiske forsøket fant ingen effekt av østrogen på insidens av hjerteinfarkt eller kardiovaskulær dødelighet blant postmenopausale kvinner (88).

Kvinner som bruker østrogen tilhører ofte en høy sosialgruppe og har en gunstigere risikoprofil enn 
andre kvinner $(87,89)$. Det kan derfor ikke utelukkes at seleksjonsbias og livsstilsforskjeller forklarer den lavere risikoen for hjerteinfarkt ved østrogenbruk i observasjonsstudiene (89). Til tross for god effekt på koronarsykdom var østrogenbruk ikke forbundet med signifikant reduksjon i total dødelighet i Nurses' Health Study (86). Østrogenbruk øker risikoen for brystkreft (87) og for tromboemboliske og kardiovaskulære episoder (90), særlig hvis østrogen kombineres med røyking (85).

Hormonsubstitusjonsbehandling har sin plass ved menopausale plager og som et bidrag i forebygging av osteoporose. Inntil det foreligger vitenskapelig basert kunnskap om at østrogensubstitusjon er like nyttig og ufarlig for alle, bør behandling institueres på klinisk indikasjon, og ikke som et generelt tiltak. Kvinnens symptomer må vurderes sammen med absolutt sykdomsrisiko og bivirkningsrisiko.

\section{AVSLUTTENDE KOMMENTARER}

Vi kjenner i dag ikke årsaken til kvinners relative beskyttelse mot hjerteinfarkt i forhold til like gamle menn. Denne kjønnsforskjellen er påvist $i$ alle kjente populasjoner selv om både livsstil og insidensrater for hjerteinfarkt varierer mye. Noen hevder at forskjellen må skyldes kvinners livsstil og evne til omsorg, varme og større sosialt nettverk i motsetning til menns aggressive og kompetitive atferd. Kanskje kan det finnes en biologisk forklaring - for eksempel gener som kjønnsspesifikt påvirker hormonelle og metabolske faktorer, og som forklarer kvinnenes fortrinn. Videre forskning må avklare disse spørsmålene. Det er også behov for forskning i Norge om der er forskjell i utredning og behandling av kvinner og menn med koronarsykdom, og om forebygging og behandling bør skje etter felles eller etter kjønnsspesifikke kriterier.

\section{REFERANSER}

1. Statistisk sentralbyrå. Dødsårsaker 1995. Oslo-Kongsvinger: Statistisk sentralbyrå, 1998.

2. Sans S, Kesteloot H, Kromhout D, on behalf of the Task Force. The burden of cardiovascular diseases mortality in Europe. Task Force of the European Society of Cardiology on cardiovascular mortality and morbidity statistics in Europe. Eur Heart J 1997; 18: 1231-1248.

3. Njølstad I, Arnesen E, Lund-Larsen PG. Smoking, serum lipids, blood pressure, and sex differences in myocardial infarction. A 12-year follow-up of the Finnmark Study. Circulation 1996; 93: 450-456.

4. Price JF, Fowkes GR. Risk factors and the sex differential in coronary artery disease. Epidemiology 1997; 8: 584-591.

5. Lerner DJ, Kannel WB. Patterns in coronary heart disease - morbidity and mortality in the sexes: a 26-year follow-up of the Framingham population. Am Heart J 1986; 111: 383-390.

6. Chaitman BR, Bourassa MG, Davis K, et al. Angiographic prevalence of high-risk coronary artery disease in patient subsets (CASS). Circulation 1981; 64: 360-367.

7. Kennedy JW, Killip T, Fisher LD, Alderman EL, Gillespie MJ, Mock MB. The clinical spectrum of coronary artery disease and its surgical and medical management, 1974-1979. The Coronary Artery Surgery Study. Circulation 1982; 66 (suppl III): III17-III23.

8. Orencia A, Bailey K, Yawn BP, Kottke TE. Effect of gender on long-term outcome of angina pectoris and myocardial infarction/sudden unexpected death. JAMA 1993; 269: 2392-2397.

9. Vaccarino V, Krumholz HM, Berkman L, Horwitz RI. Sex differences in mortality after myocardial infarction. Is there evidence for an increased risk for women? Circulation 1995; 91: 1861-1871.

10. Benderley M, Behar S, Reicher-Reiss H, Boyko V, Goldbourt U, for the SPRINT Study Group. Long-term prognosis of women after myocardial infarction. Am J Epidemiol 1997; 146: 153-160.

11. Vaccarino V, Parsons L, Every NR, Barron HV, Krumholz HM, for the National Registry of Myocardial Infarction 2 Participants. Sex based differences in early mortality after myocardial infarction. $N$ Engl J Med 1999; 341: 217-225.

12. Malacrida R, Genoni M, Maggioni AP, et al, for the Third International Study of Infarct Survival Collaborative Group. A comparison of the early outcome of acute myocardial infarction in women and men. $N$ Engl $J$ Med 1998; 338: 8-14.

13. Mendelson MA, Hendel RC. Myocardial infarction in women. Cardiology 1995; 86: 272-285.

14. Wilcox RG, Hampton JR. Importance of age in prehospital and hospital mortality of heart attacks. Br Heart J 1980; 44: 503-507.

15. Njølstad I, Arnesen E. Preinfarction blood pressure and smoking are determinants for a fatal outcome of myocardial infarction. A prospective analysis from The Finnmark Study. Arch Intern Med 1998; 158: 1326-1332. 
16. Maynard C, Every NR, Martin JS, Kudenchuk PJ, Weaver WD. Association of gender and survival in patients with acute myocardial infarction. Arch Intern Med 1997; 157: 1379-1384.

17. Wexler LF. Studies of acute coronary syndromes in women - lessons for everyone (Editorial). Lancet 1999; 341: $275-276$.

18. Chambless L, Keil U, Dobson A, et al, for the WHO MONICA Project. Population versus clinical view of case fatality from acute coronary heart disease. Results from the WHO MONICA Project 1985-1990. Circulation 1997; 96: 3849-3859.

19. Sonke GS, Beaglehole R, Stewart AW, Jackson R, Stewart FM. Sex differences in case fatality before and after admission to hospital after acute cardiac events: analysis of community based coronary heart disease register. BMJ 1996; 313: 853-855.

20. Nyboe J, Jensen G, Appleyard M, et al. Smoking and the risk of first myocardial infarction. Am Heart J 1991; 122: $438-447$

21. Prescott E, Hippe M, Schnohr P, Hein HO, Vestbo J. Smoking and risk of myocardial infarction in women and men: longitudinal population study. BMJ 1998; 316: 1043-1047.

22. Baron JA, La Vecchia C, Levi F. The antiestrogenic effect of cigarette smoking in women. Am J Obstet Gynecol 1990; 162: 502-514.

23. Department of Health and Human Services. Epidemiology. In: National Heart, Lung, and Blood Institute. Report of the Task Force on Research in Epidemiology and Prevention of Cardiovascular Diseases. Rockville, MD: Public Health Service, National Institutes of Health, 1994: 19-72.

24. Rosenberg L, Palmer JR, Shapiro S. Decline in the risk of myocardial infarction among women who stop smoking. N Engl J Med 1990; 322: 213-217.

25. Statens tobakksskaderåd. Fylkesvis røykestatistikk for 1997. Pressemelding. Oslo: Statens tobakksskaderåd, 1998.

26. Palmer JR, Rosenberg L, Shapiro S. "Low yield" cigarettes and the risk of nonfatal myocardial infarction in women. N Engl J Med 1989; 320: 1569-1573.

27. Bush TL, Fried LP, Barrett-Connor E. Cholesterol, lipoproteins and coronary heart disease in women. Clin Chem 1988; 34: B60-B70.

28. Stensvold I, Tverdal A, Urdal P, Graff-Iversen S. Non-fasting serum triglyceride concentration and mortality from coronary heart disease and any cause in middle aged Norwegian women. BMJ 1993; 307: 1318-1322.

29. LaRosa JC. Triglycerides and coronary risk in women and the elderly. Arch Intern Med 1997; 157: 961-968.

30. Barrett-Connor EI, Cohn BA, Wingard DL, Edelstein SI. Why is diabetes mellitus a stronger risk factor for fatal ischemic heart disease in women than in men? The Rancho Bernardo Study. JAMA 1991; 265: 627-631.

31. Njølstad I, Arnesen E, Lund-Larsen PG. Sex differences in risk factors for clinical diabetes mellitus in a general population: a 12-year follow-up of the Finnmark Study. Am J Epidemiol 1998; 147: 49-58.

32. Selmer R. Blood pressure and twenty-year mortality in the city of Bergen, Norway. Am J Epidemiol 1992; 136: $428-440$.

33. Holmen J, Midthjell K, Bjartveit K, et al. Nord-Trøndelag Health Survey 1984-86. Statens institutt for folkehelse, Senter for samfunnsmedisinsk forskning, Verdal. Rapport 4, 1990.

34. Powell KE, Thompson PD, Caspersen CJ, Kendrick JS. Physical activity and the incidence of coronary heart disease. Annu Rev Public Health 1987; 8: 253-287.

35. Salonen JT, Puska P, Tuomilehto J. Physical activity and risk of myocardial infarction, cerebral stroke and death: a longitudinal study in eastern Finland. Am J Epidemiol 1982; 115: 526-537.

36. Lapidus L, Bengtsson C. Socioeconomic factors and physical activity in relation to cardiovascular disease and death: a 12 year follow up of participants in a population study of women in Gothenburg, Sweden. Br Heart J 1986; 55: 295-301.

37. Blair SN, Kohl HW, Paffenbarger RS Jr, et al. Physical fitness and all-cause mortality: a prospective study of healthy men and women. JAMA 1989; 262: 2395-2401.

38. Løchen ML. Arrhythmia, electrocardiographic signs, and physical activity in relation to coronary heart risk factors and disease. The Tromsø Study. Doktoravhandling. Tromsø: Institutt for samfunnsmedisin og Institutt for klinisk medisin, Universitetet i Tromsø, 1995.

39. Barrett-Connor E. Sex differences in coronary heart disease. Circulation 1997; 95: 252-264.

40. Blair SN. Evidence for success of exercise in weight loss and control. Ann Intern Med 1993; 119: $702-706$.

41. Løchen ML, Rasmussen K. The Tromsø study: physical fitness, self reported physical activity, and their relationship to other coronary risk factors. J Epidemiol Community Health 1992; 26: 103-107. 
42. Reaven PD, Barrett-Connor E, Edelstein S. Relation between leisure-time physical activity and blood pressure in older women. Circulation 1991; 83: 559-565.

43. Thune I, Njølstad I, Løchen ML, Førde OH. Physical activity improves the metabolic risk profiles in men and women. Arch Intern Med 1998; 158: 1633-1640.

44. Stevenson ET, Davy KP, Seals DR. Hemostatic, metabolic, and androgenic risk factors for coronary heart disease in physically active and less active postmenopausal women. Arterioscler Thromb Vasc Biol 1995; 15: 669-677.

45. Williams PT, Krauss RM, Vranizan KM, et al. Changes in lipoprotein subfractions during diet-induced and exercise-induced weight loss in moderately overweight men. Circulation 1990; 81: 1293-1304.

46. Krotkiewski M, Björntorp P. Muscle tissue in obesity with different distribution of adipose tissue. Int J Obes Relat Metab Disord 1986; 10: 331-341.

47. Lokey EA, Tran ZV. Effects of exercise training on serum lipid and lipoprotein concentrations in women: a meta-analysis. Int J Sports Med 1989; 10: 424-429.

48. Lundgren $\mathrm{H}$, Bengtsson $\mathrm{C}, \mathrm{Blohme} \mathrm{G}$, et al. Adiposity and adipose tissue distribution in relation to incidence of diabetes in women: results from a prospective population study in Gothenburg, Sweden. Int J Obes 1989; 13: 413-423.

49. Larsson B, Bengtsson C, Björntorp P, et al. Is abdominal body fat distribution a major explanation for the sex difference in the incidence of myocardial infarction? The study of men born in 1913 and the study of women, Göteborg, Sweden. Am J Epidemiol 1992; 135: 266-273.

50. Gueyffier F, Boutitie F, Boissel JP, et al (The INDANA Investigators). Effect of antihypertensive drug treatment on cardiovascular outcomes in women and men. A meta-analysis of individual patient data from randomized, controlled trials. Ann Intern Med 1997; 126: 761-767.

51. Hewitt S, Sandvig A, Wøien G, Graff-Iversen S. Utvikling av risikofaktorer for hjerte- og karsykdommer hos 40-42-åringer i Finnmark fylke 1973-93. Tidsskr Nor Laegeforen 1995; 115: 3719-3723.

52. Law MR, Wald NJ, Thompson SG. By how much and how quickly does reduction in serum cholesterol concentration lower risk of ischaemic heart disease? BMJ 1994; 308: 367-372.

53. Furberg CD, Adams HP, Applegate WB, et al, for the Asymptomatic Carotid Artery Progression Study (ACAPS) Research Group. Effect of lovastatin on early carotid atherosclerosis and cardiovascular events. Circulation 1994; 90: 1679-1687.

54. Miettinen TA, Pyörälä K, Olsson AG, et al, for the Scandinavian Simvastatin Study Group. Cholesterollowering therapy in women and elderly patients with myocardial infarction or angina pectoris. Findings from the Scandinavian Simvastatin Survival Study (4S). Circulation 1997; 96: 4211-4218.

55. Sacks FM, Pfeffer MA, Moye LA, et al, for the Cholesterol and Recurrent Events Trial Investigators. The effect of pravastatin on coronary events after myocardial infarction in patients with average cholesterol levels. N Engl J Med 1996; 335: 1001-1009.

56. Peto R, Gray R, Collins R, et al. Randomised trial of prophylactic daily aspirin in British male doctors. $\mathrm{Br}$ Med J (Clin Res Ed) 1988; 296: 313-316.

57. Steering Committee of the Physicians' Health Study Research Group: Final report on the aspirin component of the ongoing Physicians' Health Study. N Engl J Med 1989; 321: 129-135.

58. Manson JA, Stampfer MJ, Colditz GA, et al. A prospective study of aspirin use and primary prevention of cardiovascular disease in women. JAMA 1991; 266: 521-527.

59. Hennekens $\mathrm{CH}$. Update on aspirin in the treatment and prevention of cardiovascular disease. Am Heart $J$ 1999; 137: S9-S13.

60. Becker RC, Terrin M, Ross R, et al. Comparison of clinical outcomes for women and men after acute myocardial infarction. Ann Intern Med 1994; 120: 638-645.

61. ISIS-2 Collaborative Group: Randomised trial of intravenous streptokinase, oral aspirin, both, or neither among 17,187 cases of suspected myocardial infarction: ISIS-2. Lancet 1988; 318: 349-360.

62. Olsson G, Wikstrand J, Warnold I, et al. Metoprolol-induced reduction in postinfarction mortality: pooled results from five double-blind randomized trials. Eur Heart J 1992; 13: 28-32.

63. Fuster V, Dyken ML, Vokonas PS, Hennekens CH. Aspirin as a therapeutic agent in cardiovascular disease. Circulation 1993; 87: 659-675.

64. Fisher LD, Kennedy JW, Davis KB, et al. Association of sex, physical size, and operative mortality after coronary artery bypass in the Coronary Artery Surgery Study (CASS). J Thorac Cardiovasc Surg 1982; 84: 334-341. 
65. Jacobs AK, Kelsey SF, Brooks MM, et al. Better outcome for women compared with men undergoing coronary revascularization. A report from the Bypass Angioplasty Revascularization Investigation (BARI). Circulation 1998; 98: 1279-1285.

66. Risum O, Abdelnoor M, Nitter-Hauge S, Levorstad K, Svennevig JL. Coronary artery bypass surgery in women and in men; early and long-term results. A study of the Norwegian population adjusted by age and sex. Eur J Cardiothorac Surg 1997; 11: 539-46.

67. Hammar N, Sandberg E, Larsen FF, Ivert T. Comparison of early and late mortality in men and women after isolated coronary artery bypass graft surgery in Stockholm, Sweden, 1980 to 1989. J Am Coll Cardiol 1997; 29: 659-664.

68. Rahimtoola SH, Bennett AJ, Grunkemeier GL, Block P, Starr A. Survival at 15 to 18 years after coronary artery bypass surgery for angina in women. Circulation 1993; 88: II71-II78.

69. Bickell NA, Pieper KS, Lee KL, et al. Referral patterns for coronary artery disease treatment: gender bias or good clinical judgment? Ann Intern Med 1992; 116: 791-797.

70. Mark DB, Shaw LK, DeLong ER, Califf RM, Pryor DB. Absence of sex bias in the referral of patients for cardiac catheterization. $N$ Engl J Med 1994; 330: 1101-1106.

71. Tobin JN, Wassertheil-Smoller S, Wexler JP, et al. Sex bias in considering coronary bypass surgery. Ann Intern Med 1987; 107: 19-25.

72. Steingart RM, Packer M, Hamm P, et al, for the Survival and Ventricular Enlargement Investigators. Sex differences in the management of coronary artery disease. $N$ Engl J Med 1991; 325: 226-230.

73. Ayanian JZ, Epstein AM. Differences in the use of procedures between women and men hospitalized for coronary heart disease. $N$ Engl J Med 1991; 325: 221-225.

74. Shaw LJ, Miller DD, Romeis JC, Kargl D, Younis LT, Chaitman BR. Gender differences in the noninvasive evaluation and management of patient with suspected coronary artery disease. Ann Intern Med 1994; 120: 559-566.

75. Clarke KW, Gray D, Keating NA, Hampton JR. Do women with acute myocardial infarction receive the same treatment as men? BMJ 1994; 309: 563-566.

76. Maynard C, Litwin PE, Martin JS, Weaver WD. Gender differences in the treatment and outcome of acute myocardial infarction. Arch Intern Med 1999; 340: 618-626.

77. Schulman KA, Berlin JA, Harless W, et al. The effect of race and sex on physicians' recommendations for cardiac catheterization. N Engl J Med 1999; 340: 618-626.

78. Tunstall-Pedoe H. Myth and paradox of coronary risk and the menopause. Lancet 1998; 351: 1425-1427.

79. Mendelsohn ME, Karas RH. The protective effects of estrogen on the cardiovascular system. $N$ Engl J Med 1999; 340: 1801-1811.

80. Jacobsen BK, Knutsen SF, Fraser GE. Age at natural menopause and total mortality and mortality from ischemic heart disease: The Adventist Health Survey. J Clin Epidemiol 1999; 52: 303-307.

81. Hu FB, Grodstein F, Hennekens CH, et al. Age at natural menopause and risk of cardiovascular disease. Arch Intern Med 1999; 159: 1061-1066.

82. Nilsen ST, Fredriksen T, Iversen O-E, Moen MH. Norske gynekologers holdninger til og praksis ved hormonsubstitusjonsbehandling i klimakteriet. Tidsskr Nor Loegeforen 1998; 118: 2940-2943.

83. Njølstad I, Løchen ML. Østrogen bør ikke brukes primærprofylaktisk mot hjerte- og karsykdom. Tidsskr Nor Lageforen 1998; 118: 4252.

84. Barrett-Connor E, Grady D. Hormone replacement therapy, heart disease, and other considerations. Annu Rev Public Health 1998; 19: 55-72.

85. Wilson PWF, Garrison J, Castelli WP. Postmenopausal estrogen use, cigarette smoking, and cardiovascular disease. N Engl J Med 1985; 313: 1038-1043.

86. Stampfer MJ, Colditz GA, Willett WC, et al. Postmenopausal estrogen therapy and cardiovascular disease. $N$ Engl J Med 1991; 325: 756-762.

87. Grodstein F, Stampfer MJ, Colditz GA, et al. Postmenopausal hormone therapy and mortality. N Engl J Med 1997; 336: 1769-1775.

88. Hulley S, Grady D, Bush TL, et al. Randomized trial of estrogen plus progestin for secondary prevention of coronary heart disease in postmenopasual women. JAMA 1998; 280: 605-613.

89. Matthews KA, Kuller LH, Wing RR, Meilahn EN, Plantinga P. Prior to estrogen replacement therapy, are users healthier than non-users? Am J Epidemiol 1996; 143: 971-978.

90. Hemminki E, McPherson K. Impact of postmenopausal hormone therapy on cardiovascular events and cancer: pooled data from clinical trials. BMJ 1997: 315: 149-153. 